\title{
GAS INFECTION
}

\section{To the Editor of The British Journal of Ophthalmology.}

Dear SIR,-I see that Captain Pringle in his interesting paper on Gas Infection of the Cornea, published in your last number, draws attention to the absence of previously recorded cases of a similar nature; I assume that he is referring to cases which have occurred during the war; the subject of Gaseous Panophthalmitis is one to which I drew attention some years ago, and I believe that I am correct in stating that I was the first in this country to record such cases.

In the Transactions, Ophthalmological Societv, U.K., Vol. XXX, p. 179, will be found a short article, in which I gave the clinical history, and an account of the bacteriology of my first case of gaseous panophthalmitis, which occurred in 1909, while in the Ophthalmic Review, Vol. XXIX, p. 161, will be found the record of my second case. At the end of this second paper will be found references to similar cases in the literature, which were all that I could find at that time. In each of my cases the bacteriology of the condition was worked out by Dr. Charles Slater, now Consulting Bacteriologist to St. George's Hospital ; I was not so fortunate as Captain Pringle in being able to watch the development of gas bubbles in the cornea. The experience of French surgeons at that time showed that it was perfectly safe to excise an eye in which gaseous panophthalmitis was present, though I am bound to admit, that in my first case I performed an evisceration.

\section{Yours faithfully,}

LoNDON, March 4, 1919.

R. R. JAMES.

\section{OBITUARY}

Last month we announced with profound regret the sudden death of Richard A. Reeve, of Toronto. He was a fellow of the American College of Surgeons and held the degree of B.A. and LL.D. of Toronto and M.D. of Queen's. In 1872 he joined the Toronto General Hospital, where he practised ophthalmology, otology, rhinology, and laryngology, and even taught chemistry when occasion oftered. He also held the post of professor of ophthalmology in the Toronto School of Medicine and later became professor of ophthalmology and otology when amalgamation took place between the University and the School of Medicine. For nearly 